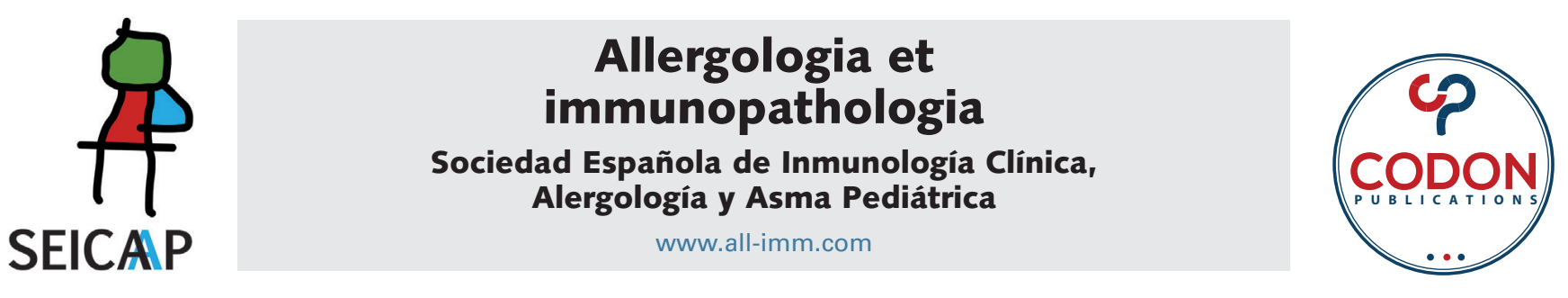

\title{
Social wasps in Spain: the who and where
}

\author{
José María Vega ${ }^{a *}$, Francisco Javier Ortiz-Sánchez ${ }^{\mathrm{b}}$, Ana Martínez-Arcedianoc, \\ Leopoldo Castro ${ }^{d}$, Teresa Alfaya ${ }^{e}$, Francisco Carballadaf, Sergia Cruz ${ }^{\mathrm{g}}$, Lluís Marqués ${ }^{\mathrm{h}}$, \\ Arantza Vega ${ }^{i}$, Berta Ruiz-León ${ }^{j}$
}

\author{
${ }^{a}$ Allergy Department, Hospital Universitario Río Hortega, Valladolid, Spain \\ ${ }^{b}$ Grupo de Investigación "Transferencia de I+D en el Área de Recursos Naturales". Universidad de Almería, Spain \\ 'Allergy and Immunology Department. Hospital Universitario Araba, Vitoria, Spain \\ 'IES Vega del Turia, Teruel, Spain \\ ${ }^{e}$ Allergy Department, Hospital Universitario Fundación Alcorcón, Madrid, Spain \\ ${ }^{f}$ Allergy Department, HULA (Hospitalario Universitario Lucus Augusti), Lugo, Spain \\ ${ }^{\text {s} A l l e r g y ~ D e p a r t m e n t, ~ H o s p i t a l ~ U n i v e r s i t a r i o ~ T o r r e c a ́ r d e n a s, ~ A l m e r i ́ a, ~ S p a i n ~}$ \\ ${ }^{h}$ Allergy Department, Hospitales Universitarios Santa María y Arnau de Vilanova, Lleida, Spain \\ ${ }^{i}$ Allergy Department, Hospital Universitario de Guadalajara, Spain. ARADyAL Spanish Thematic Network and Co-operative Research \\ Centre RD16/0006/0023 Instituto de Salud Carlos III, Madrid \\ ${ }^{j}$ Allergy Department, Hospital Universitario Reina Sofía, Córdoba, Spain. ARADyAL Spanish Thematic Network and Co-operative \\ Research Centre RD16/0006/0018, Instituto de Salud Carlos III, Madrid; Instituto Maimónides de Investigación Biomédica, Córdoba
}

Received 6 October 2021; Accepted 28 October 2021

Available online 1 March 2022

\section{KEYWORDS}

immunotherapy;

Polistes dominula;

Vespa velutina;

vespid distribution;

Vespula

\begin{abstract}
Objective: The objective of this study was to list the social vespids occurring in Spain, determine their presence in each region, and correlate the data with the vespids responsible for allergic reactions and their progression over time.

Methods: Insects distribution data were collected in two phases: from the southern half of Spain (2008-2012), and from the northern half of Spain (2016-2019). Data for the vespids were collected from the prescriptions of Hymenoptera venom immunotherapy (HVIT) at six Spanish hospitals in the years 2009 and 2019.

Results: Polistes dominula and Vespula germanica were the most widely distributed species. Vespa velutina was found to be present in a large part of northern Spain. During the 10 year period, the prescriptions of vespid VIT increased by $42.63 \%$. The north of Spain saw a 3.61 fold greater predominance of prescriptions for Vespula (to some extent influenced by Vespa velutina allergy) whereas in central and southern Spain, there was a 3.97 fold greater predominance of prescriptions for Polistes.

Conclusions: It is the first study that compares the vespid distribution maps with VIT prescription. A noteworthy finding is the wide presence of Polistes dominula and Vespula germanica in
\end{abstract}

\footnotetext{
*Corresponding author: Vega JM, Allergy Department. Hospital Universitario Río Hortega, Dulzaina 2, 47012 Valladolid, Spain. Email address: jvegag2002@yahoo.es
} 
Spain and the appearance of Vespa velutina allergy in the northern part of the country. Data of HVIT prescriptions reflect inter-regional variability with the predominance of Vespula (due to Vespula and Vespa) in the north and that of Polistes in the center and south of Spain. (c) 2022 Codon Publications. Published by Codon Publications.

\section{Introduction}

Vespids belong belong to a hymenopteran family (Vespidae) with a practically worldwide distribution. The family contains six subfamilies, of which three include mostly solitary species and the other three only social or inquiline species; two of the social groups, Polistinae and Vespinae, occur in Spain. Social wasps build nests that they defend against potential predators with their sting, which most likely causes allergic reactions in local population. Understanding the distribution of wasps would be very useful for allergologists to correctly diagnose and treat the reactions caused by them.

The Spanish fauna of social vespids is made up of 24 species (10 of the genus Polistes, 6 of Dolichovespula, 4 each of Vespa and Vespula). This includes euryoic species, found in a wide range of ecosystems and at widely differing altitudes ( $P$. dominula, $P$. gallicus, $P$. austroccidentalis, $P$. nimpha, D. sylvestris, Vespula germanica, Vespula vulgaris, and Vespa crabro). Some mountain-dwelling species, which are more or less widespread in the north and south of Spain, only appear at a few high-altitude enclaves ( $P$. biglumis, $P$. atrimandibularis, and $D$. omissa) whereas several mountain species are absent from the south $(P$. semenowi, $D$. adulterina and $D$. norwegica), and some species are restricted to a few habitats (wooden or humid areas in the case of Vespa velutina, V. austriaca, D. media, and V. rufa; and marshy areas in the case of $P$. bischoffi).

Some species have been introduced exogenously ( $P$. major, Vespa bicolor, Vespa orientalis, and Vespa velutina), each having established themselves to varying degrees. Finally, some social parasitic species, such as $P$. atrimandibularis, $P$. austroccidentalis, $P$. semenowi, D. adulterina, $D$. omissa, and Vespula austriaca, also exist., ${ }^{1,2}$

In Spain, vespids have been studied for several decades but in an isolated manner with no clear timeline. ${ }^{3-12}$ Studies conducted on patients allergic to Hymenoptera venom have provided indirect data and have demonstrated inter-regional variability in the distribution of two main allergenic vespid genera with a predominance of $P$. dominula in southeastern Spain and Vespula germanica in the northwest..$^{13-16}$ In Europe, to date, a considerable sensitization to venom from the genera Vespula and Polistes has been observed in the Mediterranean regions, while in the north and center of Europe sensitization to Polistes is rare. ${ }^{15,17}$ Furthermore, the arrival of new invasive species $^{18-21}$ and the appearance of cases of allergy to their venom $^{22-24}$ have led to an increase in the vespid species which are of interest to allergologists in Spain.

The objective of this study was to list the main social vespids found in Spain by elaborating distribution maps, and to correlate these data with the vespids responsible for allergic reactions in six Spanish provinces and their progression over time.

\section{Material and Methods}

A prospective observational study was conducted at the national level by entomologists and the Hymenoptera Committee of the Spanish Society of Allergy and Clinical Immunology (SEAIC) in which data on the distribution (presence) of 24 species of social vespids were collected: 10 from the genus Polistes ( $P$. associus, $P$. atrimandibularis, $P$. austroccidentalis, $P$. biglumis, $P$. bischoffi, $P$. dominula, $P$. gallicus, $P$. major, $P$. nimpha, and $P$. semenowi), 4 of Vespula (V. austriaca, V. germanica, V. rufa, and V. vulgaris), 6 of Dolichovespula (D. adulterina, D. media, D. norwegica, D. omissa, D. saxonica, and $D$. sylvestris), and 4 of Vespa (V. bicolor, V. crabro, V. orientalis, and V. velutina).

Results were collected in the following two different but complementary ways.

\section{Bibliographic review of published studies on the presence of different vespid species. The following sources were consulted:}

- Entomological journals as cited in the References.

- Online access to databases of public and private organizations.

- An Internet search of entomology-related pages and discussion groups. Pages such as Biodiversidad virtual (Virtual Biodiversity) and Facebook fora were consulted.

\section{Field sampling}

The collection and identification of vespids captured (mainland Spain, the Balearic Islands, and Melilla) was carried out in two phases: in the first phase (2008-2012), data were collected from the southern half of Spain, and in the second phase (2016-2019), the northern part of the country was studied. The Canary Islands were excluded because they represent a different biogeographic area with a very different fauna. The provinces in which the field samples were taken in each of the phases of the study are shown in Figure 1.

At the same time, data (number of prescriptions) of Hymenoptera venom immunotherapy (HVIT) were collected retrospectively on yearly initiation and maintenance VIT at two time points separated by 10 years (2009 and 2019) in the Allergology Departments of six Spanish hospitals, three in the north (Hospital Universitario Lucus Augusti in Lugo, Hospital Universitario Araba in Álava, and Hospital Santa María in Lleida) and another three in the center and south of the country (Hospital Universitario in Guadalajara, Hospital General Universitario in Ciudad Real, and Hospital Reina Sofía in Córdoba). VIT was prescribed 


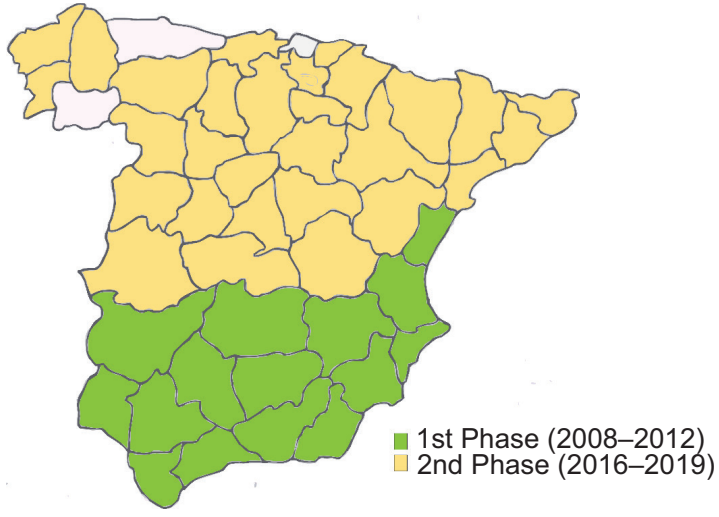

Figure 1 Spanish provinces in which field sampling was conducted with collection and identification of social vespids.

to all the patients diagnosed with hymenopteran venom allergy, who developed a systemic allergic reaction after a sting, and presented positive specific immunoglobulin $\mathrm{E}$ (IgE) against the venom involved. Data on VIT were collected against Apis mellifera, Polistes dominula, and Vespula spp., and double immunotherapy against Polistes dominula and Vespula spp. in patients in whom it was not possible to precisely determine the vespid involved. The cases of suspected allergic reaction to Vespa velutina and Vespa crabro requiring VIT were counted independently (although Vespula VIT was prescribed to all patients except one, who, due to molecular diagnostic profile, was prescribed $P$. dominula VIT).

\section{Results}

The most widely distributed species were $P$. dominula and Vespula germanica. These were followed in frequency by $P$. nimpha and $P$. gallicus. Among the very scarce species, the following are worth highlighting: $P$. associus, $P$. atrimandibularis, $P$. semenowi, $D$. adulterina, $D$. omissa, $D$. saxonica, and $V$. austriaca. Figure 2 shows the distribution data for the 24 studied vespids.

Concerning the results of the data on prescribing VIT, 582 prescriptions were recorded (108 initiation and 474 maintenance) in 2009, with bee venom predominating and accounting for 294 (50.51\%) prescriptions.

In 2019, the overall number of prescriptions for VIT rose to 813 (28.41\%). Of these, 177 (38.98\%) were cases of VIT initiation and 636 (25.47\%) VIT maintenance, in particular against vespids, which increased by $42.63 \%$ (Polistes increased by $35.92 \%$, Vespula $14.47 \%$, and double VIT by $78.57 \%)$. However, in the north of Spain, honeybee VIT fell by $40.88 \%$ (from 225 prescriptions in 2009 to 133 in 2019). In this area, when a comparison was made between Polistes and Vespula VIT, a 3.61-fold predominance (94/26) of cases of Vespula VIT was observed in 2009 and a 2.58-fold predominance (111/43) in 2019. Furthermore, in this area, 24 patients required VIT due to Vespa velutina venom. However, in the south of Spain, the predominance of Polistes VIT was 2.94 times (106/36) higher in 2009 and 3.97 times (163/41) higher in 2019. In both areas, the increase in prescriptions was higher for Polistes: in the north it increased by 38.1\% (26 in 2009 and 42 in 2019) as compared to VIT against Vespula which increased by $13.76 \%$ (94 in 2009 and 109 in 2019). In the south, Polistes VIT increased by $34.97 \%$ (106 in 2009 and 163 in 2019) and Vespula VIT by 12.2\% (36 in 2009 and 41 in 2019). Figure 3 shows the comparison of VIT initiation by areas in 2009 and 2019.

\section{Discussion}

This study established the current distribution of social vespids in Spain and demonstrated the wide distribution of $P$. dominula in all Spanish provinces, closely followed by Vespula germanica, which is also a widely distributed species. The data available to date came from local entomological field studies focusing on a single species or inventories of species from a specific area and at a particular point in time (e.g., Nieves et al. $)^{25}$ and did not allow comparisons to be made with earlier similar studies.

As allergologists, we already have indirect data on the distribution of social vespids obtained from studies into the incidence and prevalence of allergic reactions following stings and VIT prescription, although this did not allow comparisons to be made over time. ${ }^{16,26,27}$ Thus, in the Spanish Alergológica studies conducted in 2005 and 2015 into the diagnosis of hypersensitivity reactions due to insects, a change was noted towards the predominance of sensitization to Polistes as compared to Vespula (2005: Vespula 27.3\%, Polistes 23.4\%; 2015: Vespula 27.3\%, Polistes 36.8\%). ${ }^{28,29}$

The data obtained in our study demonstrated a prominent increase $(43 \%)$ in the prescription of vespid VIT. The geographical differences remained the same for both areas, with Vespula being more common in the north and Polistes in the center and south of the peninsula, although with a greater increase in the prescription of Polistes VIT in both areas. $P$. dominula is a very widespread species, present in a diverse range of environments. It originates from the Mediterranean area and its expansion toward the center and north of Europe has been linked to global warming. ${ }^{30}$ Furthermore, its invasiveness in parts of the world where it has been introduced is related to the shorter time needed for the larvae and pupae to develop, which gives it greater reproductivity potential than other Polistes species, thus displacing them in such countries. ${ }^{31}$ The invasion of Vespa velutina in the north of Spain and the severity of reactions in patients exposed to its venom have led to a fresh need for VIT, and it would be advisable to have available the corresponding diagnostic and therapeutic methods specific to this species. ${ }^{32}$ Finally, it is noteworthy that the prescriptions of Apis mellifera VIT have fallen by $41 \%$ in the north of Spain. These data need to be analyzed with caution, bearing in mind the sudden appearance of Vespa velutina and climate change.

The present study has its limitations, as the species mapping data were collected on the presence of species in particular areas but not their density, which logically has implications on the risk of stings and accounts for the differences in the distribution of VIT prescription. Another limitation was that we collected only VIT data from six hospitals; however, its distribution (three in the north and another three in the center and south of the country) supports the data representativeness. Furthermore, 

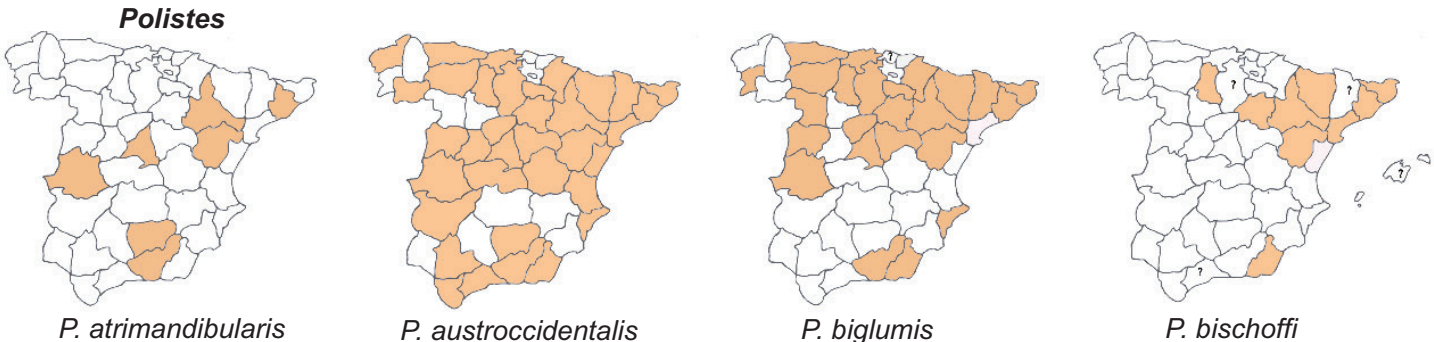

$P$. atrimandibularis

P. austroccidentalis

P. biglumis
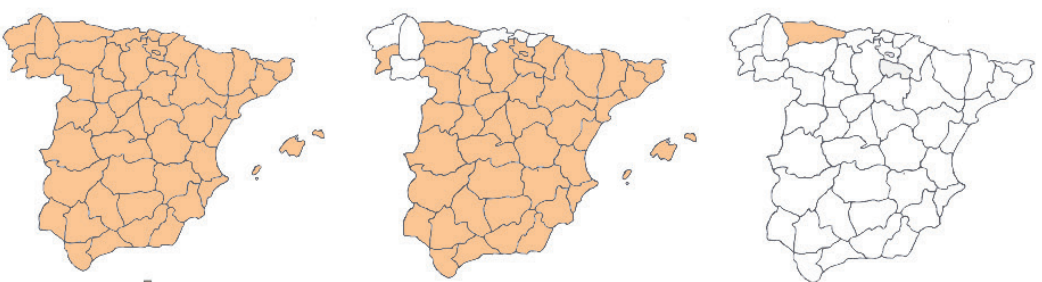

P. dominula

$P$. gallicus

P. major

Dolichovespula
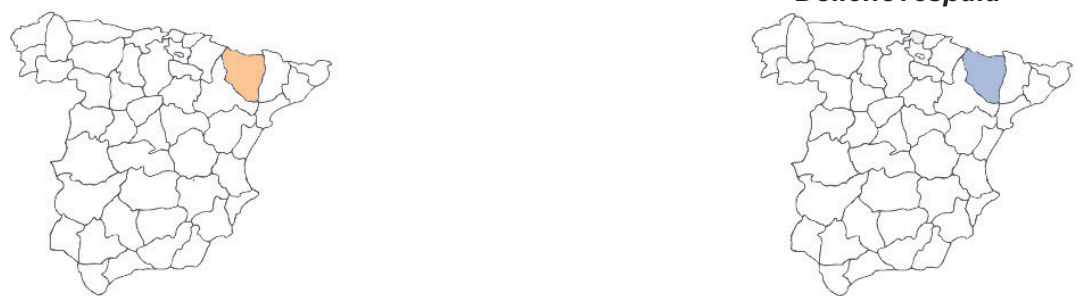

P. bischoffi

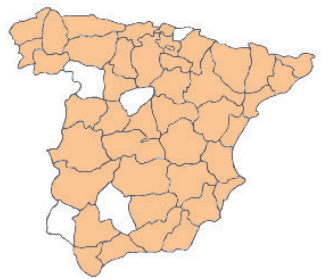

P. nimpha

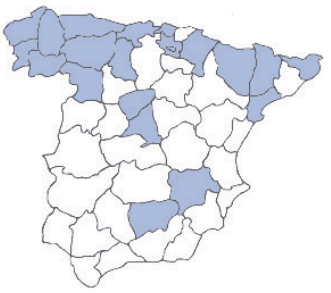

P. semenowi
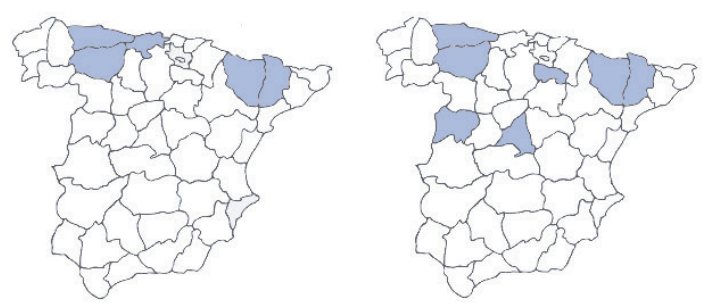

D. adulterina

D. media
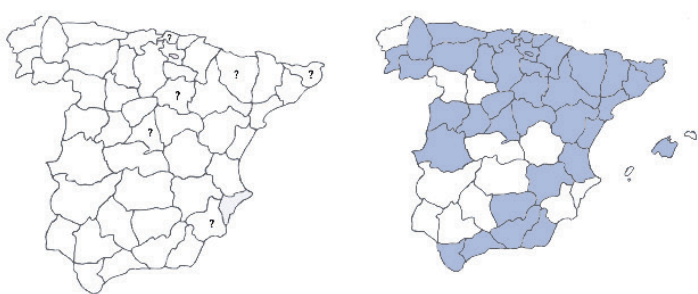

D. omissa

D. saxonica

D. sylvestris
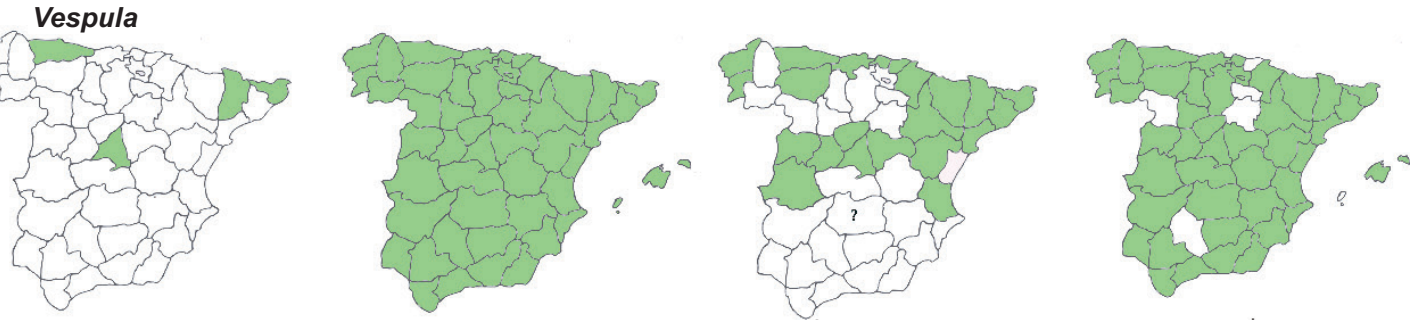

V. austriaca

V. germanica

V. rufa

V. vulgaris
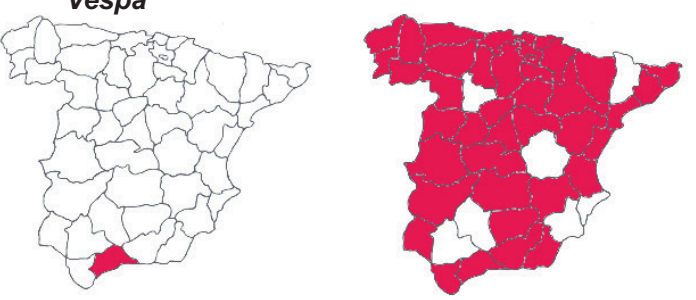

V. crabro

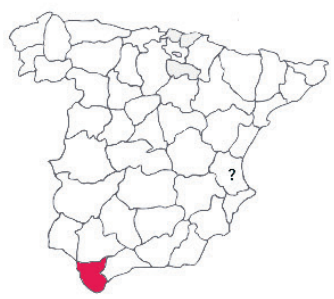

V. orientalis

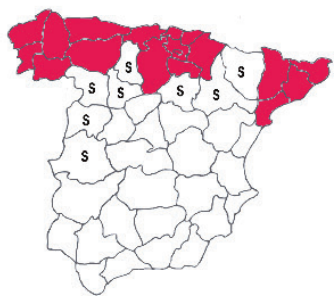

V. velutina

Figure 2 Distribution maps of Spanish social vespids. Confirmed presence= colored provinces; doubtful presence= ?; sporadic or accidental presence= S. Data were collected up to 31st December, 2019. 

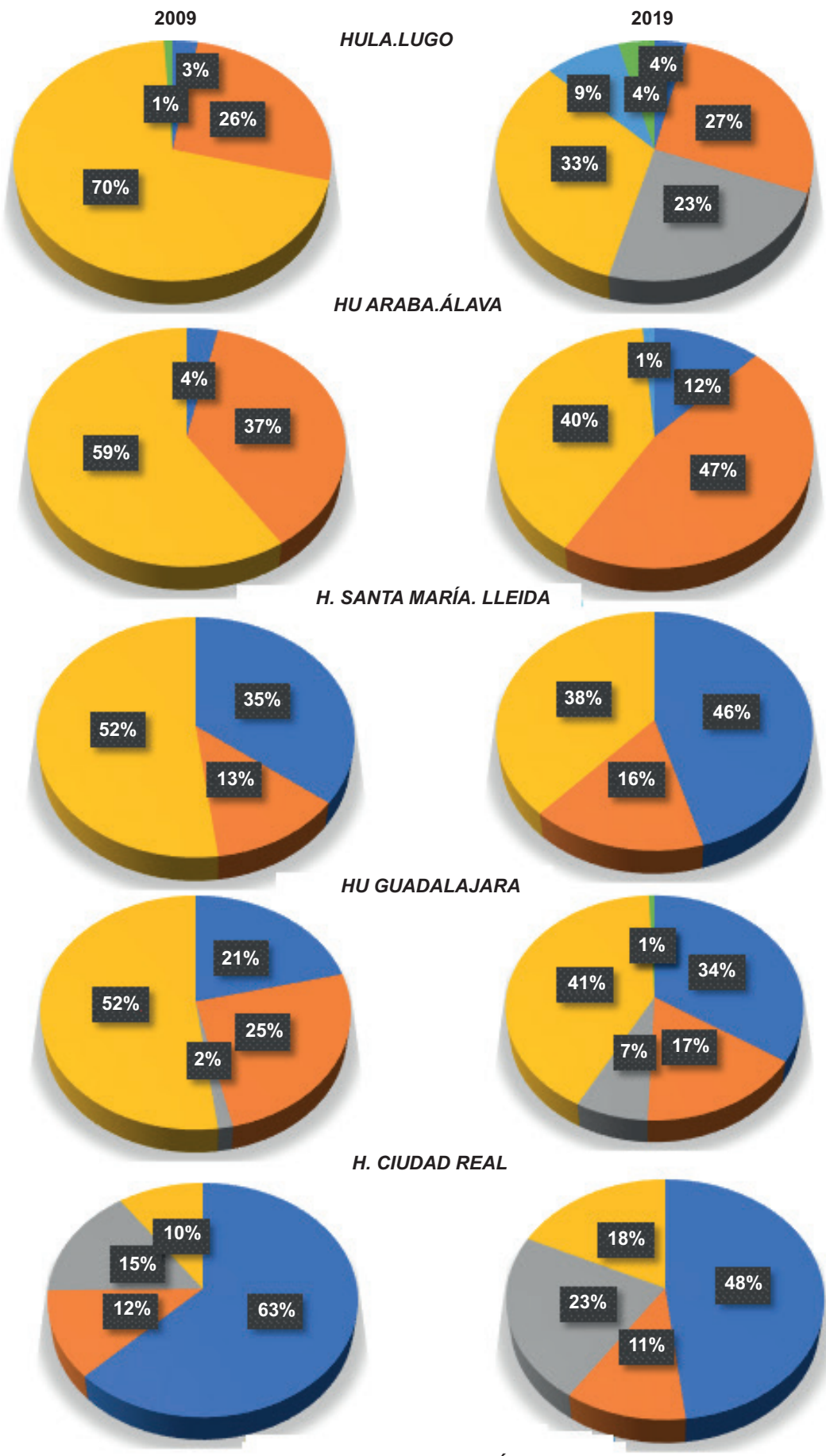

HU GUADALAJARA
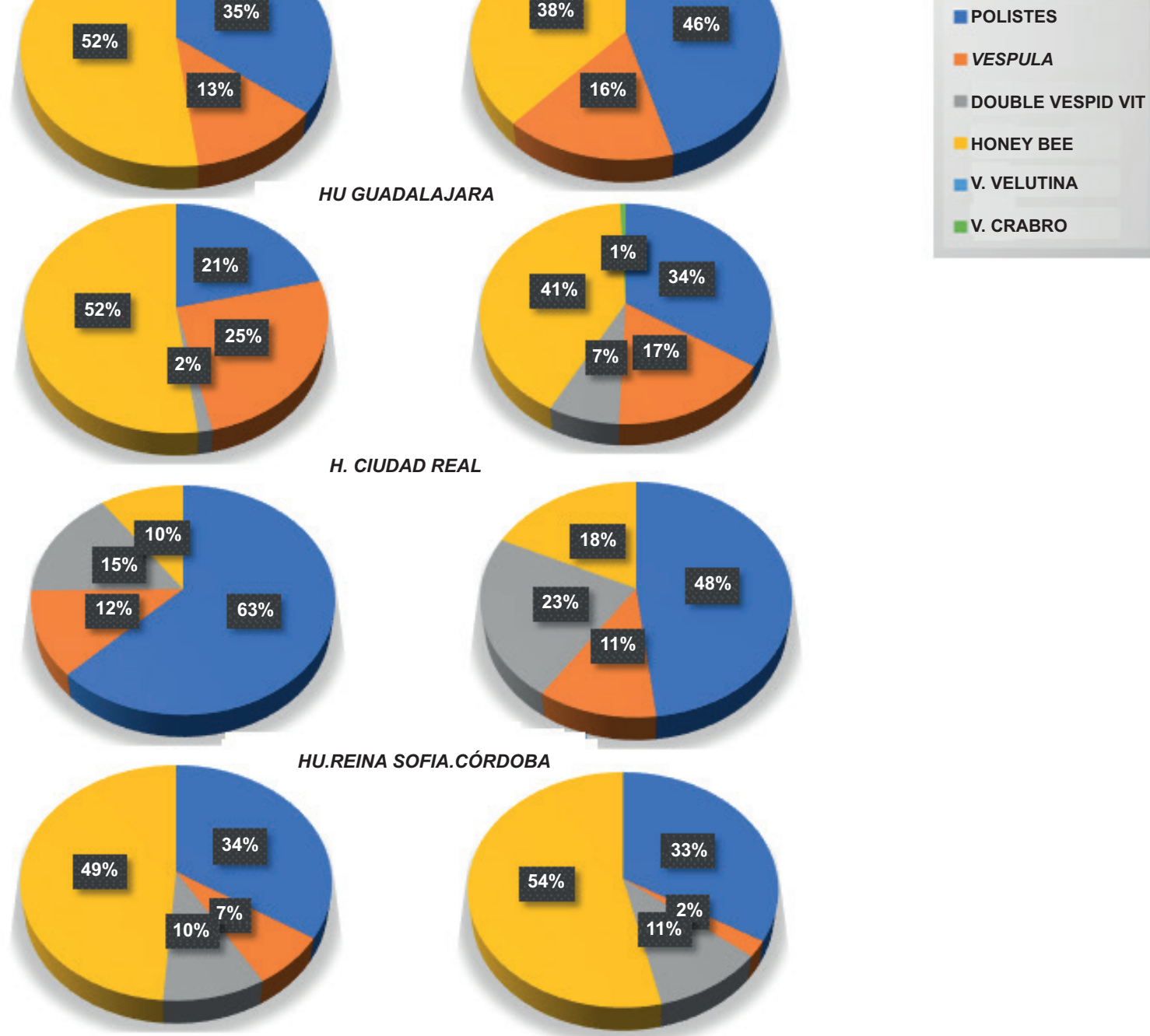

U.REINA SOFIA.CÓRDOBA

Figure 3 Hymenoptera venom immunotherapy in 2009 and 2019 in 6 Spanish hospitals. 
for diagnostic purposes, we only had at our disposal commercialized venoms from some species, and the possible cross-reactivity between these makes difficult the precise diagnosis of the species involved.

\section{Conclusions}

This is the first study that compares the vespid distribution maps with VIT prescription. A noteworthy finding is the presence of $P$. dominula in all provinces of Spain and the appearance of Vespa velutina in the northern part of the country. Data on the prescription of VIT reflect the inter-regional variability with the predominance of Vespula (due to Vespula and Vespa) in the north and that of Polistes in the the center and south of Spain, although there was an increase of Polistes VIT in both areas. Global warming and the accidental introduction of invasive species will most likely continue to cause changes in the distribution of these and other insects which have repercussions for human health, changes which allergologists need to be aware of.

\section{References}

1. Carpenter JM. Distributional checklist of the species of the genus Polistes (Hymenoptera: Vespidae; Polistinae, Polistini) [Internet]. [Accessed 2009 April 5]. Available from: http:// www.ipc.ibaraki.ac.jp/ jkrte/wasp/polistes/Polistes.htm.

2. Carpenter JM, Kojima J. Checklist of the species in the subfamily Vespinae. Nat Hist Bull Ibaraki Univ. 1997;1:51-92. Record Number 20067204118

3. Baldock DW, Livory A, Owens N. The bees and wasps of the Balearic Islands. Entomofauna. 2020;Supplement 25:1-202.

4. Castro L, Carbonell R. Presencia de Polistes bischoffi Weyrauch, 1937 (Hymenoptera, Vespidae) en Cataluña (Península Ibérica). Butlletí de la Institució Catalana d'Historia Natural. 2016;80:25-7. ISSN 1133-6889

5. Castro L. Los Véspidos. In: Ruano F, Tierno de Figueroa M, Tinaut A, editors. Los Insectos de Sierra Nevada. 200 años de historia. Salamanca, Spain: Asociación Española de Entomología; 2013; pp. 411-29.

6. Castro L, Sanza F. Aportación al conocimiento de los Vespidae (Hymenoptera) de Sierra Nevada (España), con algunos comentarios taxonómicos. Boletín de la Sociedad Entomológica Aragonesa. 2009;45:259-78.

7. Castro L, Sanza, F, Aguirre-Segura A y Ortiz-Sánchez FJ. Vespidae y Scoliidae (Hymenoptera) del Parque Natural Cabo de Gata-Níjar (Almería, España): Lista preliminar. Boletín de la Sociedad Entomológica Aragonesa. 2008;43:319-24.

8. De la Nuez A, González JA, Gayubo SF, Torres F. Abundancia y diversidad de avispas sociales (Hymenoptera: Vespidae) en el Parque Natural de "Arribes del Duero" (oeste español). Boletín de la Sociedad Entomológica Aragonesa. 2003;32:87-93.

9. Ocharan FJ, Anadón MA, Melero VX, Monteserín S, Ocharan R, Rosa $\mathrm{R}$, et al. Invertebrados de la reserva natural integral de Muniellos, Asturias: Consejería de Medio Ambiente, Ordenación del territorio e infraestructuras del Principado de Asturias/KRK Ediciones. Oviedo; 2003. ISBN: 8496119378

10. Castro L. Catalogus: 25. Insecta: Hymenoptera. Familia 3: Vespidae (y 2). Vespidae: Subfamilias Masarinae, Polistinae, Vespinae. Catalogus Entomofauna Aragonesa. 2001;25:11-4.

11. Castro L. Sobre los Vespidae s.l. de los Monegros (Hymenoptera, Vespoidea). In: Melic A, Blasco-Zumeta J, editors. Manifiesto científico por los Monegros. Boletín de la Sociedad Entomológica Aragonesa. 1999;24:157-61.

12. Madero A. Conocimiento actual de la distribución de los véspidos en España. Actas III Congr. Ibér. Ent. 1988; 405-16.

13. Marqués L. Alergia al veneno de himenópteros. J Investing Allergol Clin Immunol. 2010;20(Supplement 2):58-72.

14. Fernández J. Distribution of vespid species in Europe. Curr Opin Allergy Clin Immunol. 2004;4(4):319-24. http://dx.doi. org/10.1097/01.all.0000136760.43571.f2

15. Fernández J, Soriano V, Mayorga L, Mayor M. Natural history of hymenoptera venom allergy in Eastern Spain. Clin Exp Allergy. 2005 Feb;35(2):179-85. https://doi. org/10.1111/j.1365-2222.2005.02169.x

16. Navarro LA, Peláez A, de la Torre F, Tenias JM, Megías J, Martínez I. Epidemiological factors on hymenoptera venom allergy in a Spanish adult population. J Invest Allergol Clin Immunol. 2004;14(2):134-41. PMID: 15301303.

17. Perez-Riverol A, Palma MS, Jakob T. Current challenges in molecular diagnostics of insect venom allergy. Allergo J Int. 2020;29:79-91. https://doi.org/10.1007/s40629-020-00119-5

18. Castro L. Una nueva introducción accidental en el género Vespa Linnaeus, 1758: Vespa bicolor Fabricius, 1787 en la provincia de Málaga (España). Revista Gaditana de Entomología. 2019;10(1):47-56.

19. Castro L, Arias A, Torralba-Burrial A. First European records of an alien paper wasp: Polistes (Aphanilopterus) major Palisot de Beauvois, 1818 (Hymenoptera: vespidae) in northern Spain. Zootaxa. 2013;3681(1):89-92. http://dx.doi.org/10.11646/ zootaxa.3681.1.7.

20. Hernández R, García-Gans FJ, Selfa J, Rueda J. Primera cita de la avispa oriental invasora Vespa orientalis Linnaeus 1771 (Hymenoptera: Vespidae) en la Península Ibérica. Boletín de la Sociedad Entomológica Aragonesa. 2013;52:299-300.

21. Castro L, Pagola-Carte S. Vespa velutina Lepeletier, 1836 (Hymenoptera: Vespidae), recolectada en la Península Ibérica. Heteropterus Revista de Entomología. 2010;10:193-6. https://doi.org/10.1111/j.1365-2338.2011.02513.x

22. Tabar Al, Joral A, Chugo S, Lizarza S, Lizaso MT, Lombardero M. Alergia a veneno de Vespa velutina como alergia emergente: Estudio de 8 casos. J Investing Allergol Clin Immunol. 2013;23(Supplement 2):71.

23. Tabar Al, Chugo S, Joral A, Lizaso MT, Alvarez MJ, Arroabaren $\mathrm{E}$, et al. Vespa Velutina Nigritorax: A new causative agent for anaphylaxis. Clin Transl Allergy. 2015;5(Suppl 3):43. https:// doi.org/10.1186/2045-7022-5-S3-P43.

24. Vidal C, Armisén M, Monsalve R, González-Vidal T, Lojo S, López-Freire $\mathrm{S}$, et al. Anaphylaxis to Vespa velutina nigrithorax: Pattern of sensitization for an emerging problem in western countries. J Investing Allergol Clin Immunol. 2021 Jun 22;31(3):228-35. https://doi.org/10.18176/jiaci.0474.

25. Nieves JL, Fontal F, Garrido AM, Rey C. Inventario de Hymenoptera (Hexapoda) en el Ventorrillo: Un rico enclave de biodiversidad en la Sierra de Guadarrama (España Central). Graellsia 2003;59:25-43. https://doi.org/10.3989/graellsia.2003.v59.i2-3.234

26. Pérez AJ, Alonso L, Prieto L, Rodríguez MI, Iglesias A, Rodríguez M. Anafilaxia por picadura de himenóptero: Estudio de 113 casos. Med Clin (Barc). 2005;125(11):417-20. https://doi. org/10.1157/13079383.

27. Martínez A, Tabar Al, Eseverri JL, Martín F, Pedemonte C. An epidemiological survey of hymenoptera venom allergy in the Spanish paediatric population. Allergol Immunopathol. 2010;38(5):259-62. https://doi.org/10.1016/j.aller.2010.02.004.

28. Marquès L, Vega A, Muñoz E, Moreno A. Epidemiologic observations on hymenoptera allergy in Spain: The Alergológica 2005 study. J Investing Allergol Clin Immunol. 2009;19(Supplement 2):51-5. PMID: 19530419. 
29. Marqués L. Alergológica 2015 report. Alergia a himenópteros. Madrid, Spain: SEAIC;2017, pp. 248-54.

30. Vega A, Castro L. Impact of climate change on insect-human interactions. Curr Opin Allergy Clin Immunol. 2019 Oct;19(5):47581. https://doi.org/10.1097/aci.0000000000000565.

31. Miller GL, Donnelly CR, Gamboa GJ. A ten-year comparative study of the population dynamics and parasitoidism in the native paper wasp Polistes fuscatus and the invasive P. dominulus. Insectes Sociaux. 2013;60(1):49-56. https://doi. org/10.1007/s00040-012-0264-4.

32. Feás X. Human fatalities caused by hornet, wasp and bee stings in Spain: Epidemiology at state and sub-state levels from 1999 to 2018. Biology (Basel). 2021 Jan 20;10(2):73. https://doi.org/10.3390/biology10020073. 